\title{
PENGARUH KEDISIPLINAN PENGGUNAAN WAKTU LUANG UNTUK BELAJAR ANTARA PRIA DENGAN WANITA
}

\author{
Vitalis Djarot Sumarwoto
}

\begin{abstract}
Abstrak
Tujuan penelitian ini hakikatnya ingin mengetahui perbedaan kedisiplinan menggunakan waktu luang antara siswa pria dengan siswa wanita pada siswa kelas XI SMA Negeri I PGRI Maospati Magetan tahun pelajaran 2010-2011. Masalah dalam penelitian ini akan menjadi lebih konkrit apabila dirumuskan sebagai berikut: "Pengaruh kedisiplinan penggunaan waktu luang untuk belajar terhadap siswa pria dengan siswa wanita".

Metode penelitian adalah eksperimen, yaitu cara mengadakan pengamatan kepada kelompok responden. Pengamatan dilakukan pada pertengahan bulan Januari sampai pertemngahan bulan Februari tahun 2011. Pelaksanaan eksperimen melibatkan konselor sekolah tempat penelitian. Penelitian ini dilaksanakandi SMA PGRI I Maospati Kabupaten Magetan tahun pelajaran 2010-2011. Sampel penelitian terdiri dari dua kelompok, yaitu kelompok siswa pria dan kelompok siswa wanita. Jumlah anggota masing-masing kelompok adalah 30 siswa, dan ditetapan dengan teknik random sampling. Pengumpulan data penelitian dengan teknik angket.Analisis data menggunakan teknik statistik, dengan rumus bangun t-score.

Hasil penelitian menunjukkan bahwa (1) ada perbedaan kedisplinan penggunaan watu luang untuk belajar antara siswa pria dan siswa wanita pada siswa kelas XI SMA PGRI 1 Maospati Kabupaten Magetan tahun pelajaran 2010-2011, dan (2) kedisiplinan siswa wanita dalam menggunakan waktu luang untuk belajar lebih baik jika dibandingkan dengan siswa pria.
\end{abstract}

Kata Kunci: kedisiplinan, waktu luang, pria, wanita

\section{Pendahuluan}

Salah satu masalah yang sering dirasakan oleh siswa Sekolah Menengah Atas PGRI I Maospati Kabupaten Magetan adalah berkaitan dengan penggunaan waktu luang untuk kegiatan yang mendukung belajarnya di sekolah. Berdasarkan hasil pengamatan penulis selama kurang lebih dua minggu memberi petunjuk bahwa banyak siswa SMA yang masih kurang atau belum peduli terhadap menggunakan waktu luang yang dimilikinya untuk kegiatan yang mendukung kegiatan belajar. 
Kesan yang penulis tangkap dan didukung oleh beberapa staf pengajar di SMA PGRI I Maospati Kabupaten Magetan, sebagian besar siswa belum maksimal dalam menggunakan waktu luangnya untuk kegiatan belajar di sekolah.

Sumadi Suryabrata (2004: 233) menyatakan bahwa ada banyak faktor yang mempengaruhi penggunaan waktu luang untuk kegiatan belajar siswa. Secara garis besar faktor-faktor tersebut meliputi (1) faktor fisiologis dan (2) faktor psikologis. Faktor fisiologis meliputi: (a) tonus jasmani pada umumnya, dan (b) keadaan fungsifungsi fisiologis tertentu, seperti status kelamin. Keadaan tonus jasmani pada umumnya dapat dikatakan melatar belakangi aktivitas belajar siswa sehari-hari. Keadaan tonus tubuh berkaitan erat dengan keadaan gizi yang terdapat dalam tubuh siswa. Artinya, banyak atau sedikitnya kandungan gisi dalam tubuh siswa itu dapat berakibat terhadap daya tubuh siswa ketika melakukan aktivitas belajar di sekolah. Keadaan fungsi-fungsi jasmani tertentu menyangkut fungsi-fungsi pancaindera (Sumadi Suryabrata (2004).

Winkel (1994: 156) secara tegas menyatakan bahwa faktor psikologis yang dapat mempengaruhi penggunaan waktu luang siswa untuk belajar dibedakan menjadi dua sub-faktor, yaitu: (1) faktor psikis yang bersifat intelektual dan (2) faktor psikis yang bersifat non-intelektual. Faktor psikis yang bersifat intelektual antara lain meliputi: inteligensi dan cara-cara belajar, yang di dalamnya adalah cara-cara menggunakan waktu luang. Faktor psikis yang bersifat non-intelektual antara lain meliputi: kedisiplinan siswa dalam menggunakan waktu luang untuk belajar.

Faktor dari luar diri siswa antara lain adalah faktor sosial. Faktor sosial erat hubungannya dengan faktor manusia yang berada di luar dirinya. Baik manusia itu hadir secara langsung atau tidak langsung bisa mempengaruhi pelaksanaan 
kedisiplinan dan penggunaan waktu luang untuk belajar. Kedisiplinan siswa dalam menggunakan waktu luang untuk kegiatan belajar dalam penelitian ini lebih ditekankan pada kegiatan belajar yang positif, yang menunjang prestasi-prestasi belajar di sekolah.

Uraian di atas memberi petunjuk bahwa faktor kedisiplinan menggunakan waktu luang untuk belajar memegang peranan penting dalam menunjang keberhasilan perkembangan siswa, khususnya yang mendukung pencapaian prestasi-prestasi di sekolah.

Siswa SMA PGRI I Maospati Magetan, apabila ditinjau dari status seksual, maka terdiri dari siswa pria dan siswa wanita. Masalahnya adalah apakah ada perbedaan kedisiplinan menggunakan waktu luang untuk belajar antara siswa pria dengan siswa wanita. Secara teoritis baik siswa pria maupun siswa wanita sebagai subyek penelitian ini berada dalam situasi, kondisi sosial dan wilayah belajar yang sama, maka semestinya tidak ada pebedaan. Namun apabila ditinjau dari sudut sosiopsikologis nampak ada perbedaan karakter antara siswa pria dengan siswa wanita. Sis Heyster (dalam Sumadi Suryabrata (2004: 222) menegaskan bahwa siswa pria lebih bersifat aktif, siswa wanita itu lebih bersifat pasif, minat siswa pria tertuju pada aspek intelektual sedang minat siswa wanita lebih tertuju pada aspek emosional.

Depdiknas (2005: 268) mengartikan kata "disiplin" sebagai tata tertib (di sekolah, kemiliteran), ketaatan atau kepatuhan kepada peraturan (tata tertib), kondisi yang merupakan perwujudan sikap mental dan perilaku seseorang (bangsa) ditinjau dari aspek kepatuhan dan ketaatan terhadap ketentuan.

Pengertian disiplin diatas, nampak jelas bahwa kata disiplin selalu dikaitkan dengan ketaatan atau kepatuhan terhadap peraturan; kondisi yang merupakan 
perwujudan sikap mental dan tingkah laku siswa dalam hubungannya dengan aspek kepatuhan dan ketaatan terhadap ketentuan yang berlaku.

Winkel (1994: 22) berpendapat bahwa dalam melaksanakan disiplin pada hakikatnya menyangkut suatu peraturan yang sedikit, tetapi jelas atau tegas dimana isi dan rumusan peraturan dipikirkan secara mantap dan matang, dibina dan dikembangkan secara lebih nyata supaya apa yang diinginkan dapat terwujud dengan baik, sesuai dengan apa yang diharapkan.

Moh. Shochib (2000: 11) menegaskan bahwa pentingnya disiplin bagi siswa dalam arti kehidupan sehari-hari di sekolah membantu siswa dalam mengembangkan dirinya secara optimal. Menumbuhkembangkan kesadaran siswa bahwa aturan atau norma yang diberlakukan di sekolah sebagai fenomena yang membebani, membelenggu aktivitas, khususnya dalam aktivitas belajar.

Kedisiplinan siswa SMA di sekolah diukur atas dasar kepatuhan dan ketaatan terhadap tata tertib yang berlaku di sekolah pada tahun 2007. Tata tertib sekolah tersebut terdiri dari kewajiban-kewajiban siswa dan larangan-larangan siswa.

Winkel (2007: 124) menyatakan bahwa faktor kegiatan belajar di sekolah tidak terlepas antara lain dari penggunaan waktu luang. Faktor penggunaan waktu luang itu oleh Winkel (2007) dikategorikan sebagai faktor di luar diri siswa, yang termasuk pada faktor pengatur proses belajar. Pendapat Winkel tersebut apabila dicermati secara seksama, maka yang dimaksud penggunaan waktu luang itu adalah cara-cara siswa dalam mengisi waktu senggang, baik ketika berada di sekolah atau di luar sekolah. Pengisian waktu senggang bertujuan melakukan kegiatan yang bersifat positif, kegiatan yang bermanfaat dalam aktivtas belajar, dan bermanfaat terhadap perkembangan pribadi. 
Djumhur dan Moh Surya (dalam Vitalis, 2002: 125) berpendapat bahwa menggunakan waktu senggang adalah bagaimana cara mengisi waktu-waktu luang dengan kegiatan-kegiatan yang produktif atau bermanfaat, baik bagi dirinya sendiri maupun bagi masyarakat. Lebih jauh Djumhur dan Moh Surya menegaskan bahwa ketidakmampuan dalam menggunakan waktu senggang kadang-kadang dapat menimbulkan masalah-masalah yang lebih besar lagi, seperti: gejala kenakalan, mengganggu ketertiban, merusak kedisiplinan.

Djumhur (dalam Vitalis, 2002: 129) berpendapat bahwa pada dasarnya penggunaan waktu luang dapat dilakukan dengan beberapa kegiatan sebagai berikut: (1) bagaimana membuat pembagian waktu secara benar, (2) mengisi waktu luang dengan hal-hal yang produktif, (3) merencanakan suatu kegiatan dalam waktu luang, dan (4) memilih kegiatan yang cocok (sesuai) dengan kemampuan, bakat dan minat yang dimilikinya.

Winkel (2007) menyatakan bahwa terdapat beberapa faktor yang mempengaruhi kedisiplinan penggunaan waktu luang untuk belajar yaitu: (1) kedisiplinan dalam mengelola waktu yang tersedia secara baik, (2) motivasi yang mendorong siswa melakukan aktivitas-aktivitas tertentu guna mencapai tujuan, (3) perhatian adalah banyak atau sedikitnya kesadaran yang menyertai sesuatu aktivitas yang dilakukan, (4) sikap adalah kesediaan bereaksi terhadap suatu hal, termasuk di penggunaan waktu luang, (5) kebiasaan adalah sesuatu yang biasa dikerjakan atau dilakukan secara berulang-ulang.

Slameto (2005) menjelaskan bahwa cara mengatasi penggunaan waktu luang bagi siswa dapat dilakukan dengan beberapa cara yaitu: (1) Sekolah membantu menyalurkan bakat dan minat siswa, (2) Sekolah dapat menyusun program belajar 
kelompok di bawah asuhan guru mata pelajaran, (3) Konselor sekolah dapat mengembangkan program layanan bim-bingan akademik atau bimbingan belajar secara intensif, (4) Melatih siswa berdisiplin dalam mengisi waktu luangnya, baik di sekolah maupun di luar sekolah, (5) Pendampingan oleh orang tua pada saat siswa melakukan aktivitas yang berkaitan dengan pengembangan diri dan pencapaian prestasi belajar, (6) Guru mata pelajaran dapat memberikan tugas rumah secara periodik, baik yang bersifat individual atau kelompok, (7) kontrol bersama antara pihak keluarga dengan pihak sekolah terhadap aktivitas siswa.

Chaplin (dalam Syah Muhibidin, 1995: 89) mengemukakan bahwa pada intinya belajar adalah perolehan perubahan tingkah laku yang relatif menetap dan proses memperoleh respon-respon sebagai akibat latihan khusus dan pengalaman. Menurut Gagne (dalam Ngalim Purwanto, 2002: 80) belajar terjadi bila suatu situasi stimulus bersama dengan isi ingatan mempengaruhi seseorang sedemikian rupa sebagai perbuatannya (performance) berubah dari waktu sebelum seseorang mengalami situasi itu ke waktu sesudah mengalami situasi itu.

Slameto (dalam Vitalis, 2003: 2) memberi pengertian bahwa belajar adalah suatu proses perubahan tingkah laku sebagai hasil dari interaksi dengan lingkungan. Slameto (dalam Vitalis, 2003: 2) menyatakan bahwa terdapat beberapa unsur dalam perbuatan belajar, yaitu: (1) belajar merupakan suatu proses perubahan dan tingkah laku, (2) belajar merupakan aktivitas mental atau psikis dalam diri seseorang, (3) perubahan itu pada pokoknya adalah didapatkannya kecakapan baru, melalui latihan dan pengalaman, (4) perubahan itu bersifat konstan atau menetap, (5) perubahan yang terjadi sebagai akibat belajar itu menyangkut berbagai aspek fisik maupun psikis, 
seperti perubahan dalam: pengertian, pengetahuan, pemahaman, ketrampilan, kebiasaan, nilai dan sikap serta prestasi-prestasi.

Pembahasan tentang siswa pria dan siswa wanita pada dasarnya menyangkut peranan seks siswa. Mary Perkins, Ryan dan John Julian Ryan (1994) menegaskan bahwa kata seks berasal dari akar kata dalam bahasa latin "secare”, yang artinya adalah memotong atau membelah. Lebih lanjut dikatakan bahwa seks perlu dipahami dalam arti seksual. Manusia pertama sering digambarkan sebagai "lelaki-perempuan”, sekaligus yang "dibelah dua” menjadi lelaki dan perempuan yang saling melengkapi. Oleh sebab itu Mary Perkin dan John Julian Ryan (1994) menyatakan "seksualitas adalah daya kodrati untuk memberikan semangat dan desakan jasmani-rohani pada dorongan seluruh hidup manusia.

Sarlito Wirawan Sarwono (dalam Vitalis, 2002: 178) menjelaskan seksualitas adalah istilah yang mencakup segala sesuatu yang berkaitan dengan seks. Selanjutnya Sarlito mengartikan seks dalam arti sempit dan dalam arti luas. Seks dalam arti yang sempit sering diartikan dalam hubungannya dengan kelamin, yang meliputi: alat kelamin itu sendiri, anggota tubuh dan ciri-ciri badaniah lainnya, yang membedakan lelaki dan perempuan. Seks dalam arti yang luas adalah segala hal yang terjadi sebagai akibat (konsekuensi) dari adanya perbedaan jenis kelamin, antara lain mencakup: (1) perbedaan tingkah laku, (2) perbedaan atribut, (3) perbedaan peran dan pekerjaan, dan (4) hubungan antara pria dengan wanita.

Perbedaan antara siswa pria dengan siswa wanita pada dasarnya bersumber pada perbedaan psikologis. Sis Heyster (dalam Sumadi Suryabrata, 2004: 191) menyatakan bahwa ada perbedaan tipe antara remaja pria dengan remaja wanita. Perbedaan tipe pada diri siswa yang sedang memasuki fase remaja membawa akibat pada perbedaan 
penghayatan terhadap sesuatu yang dihadapinya. Salah satu bentuk penghayatan tersebut adalah kedisiplinan siswa dalam menggunakan waktu luang untuk belajar di sekolah. Pada siswa pria mempunyai kecenderungan lebih aktif, memiliki kecenderungan untuk memberi perlindungan, aktif mencari informasi yang bermanfaat baginya, dan minatnya lebih ditujukan kepada hal-hal yang logis (rasional). Sedangkan siswa wanita mempunyai kecenderungan lebih pasif, memiliki kecenderungan menerima perlindungan, lebih pasif dalam memperoleh informasi yang bermanfaat baginya, minatnya lebih ditujukan kepada hal-hal yang konkrit dan cenderung lebih emosional.

Tujuan penelitian ini hakikatnya ingin mengetahui perbedaan kedisiplinan menggunakan waktu luang antara siswa pria dengan siswa wanita pada siswa kelas XI SMA Negeri I PGRI Maospati Magetan tahun pelajaran 2010-2011. Masalah dalam penelitian ini akan menjadi lebih konkrit apabila dirumuskan sebagai berikut: "Pengaruh kedisiplinan penggunaan waktu luang untuk belajar terhadap siswa pria dengan siswa wanita”.

\section{Metode Penelitian}

Metode penelitian adalah eksperimen, yaitu cara mengadakan pengamatan kepada kelompok responden. Pengamatan dilakukan pada pertengahan bulan Januari sampai pertemngahan bulan Februari tahun 2011. Pelaksanaan eksperimen melibatkan konselor sekolah tempat penelitian.

Penelitian ini dilaksanakandi SMA PGRI I Maospati Kabupaten Magetan tahun pelajaran 2010-2011. Tempat penelitian ini beralamatkan di Jalan Raya Jurusan Ngawi, Kecamatan Maospati, Kabupaten Magetan. Pelaksanaan penelitian pada bulan Januari sampai bulan Februari tahun 2011. 
Populasi penelitian adalah semua siswa kelas XI SMA PGRI I Maospati Kabupaten Magetan tahun pelajaran 2010-2011. Jumlah anggota populasi penelitian adalah 128 siswa, yang terdiri atas 35 siswa pria dan 93 siswa wanita.

Sampel penelitian terdiri dari dua kelompok, yaitu kelompok siswa pria dan kelompok siswa wanita. Jumlah anggota masing-masing kelompok adalah 30 siswa, dan ditetapan dengan teknik random sampling.

Pengumpulan data penelitian dengan teknik angket. Angket disusun dalam bentuk pilihan ganda dengan empat alternatif jawaban: a : selalu, b: sering, c: kadangkadang, dan D: tidak pernah. Banyaknya item angket yang disediakan adalah 15 butir. Angket diberikan kepada kelompok anggota siswa pria dan siswa wanita. Hasil kedua isian angket tersebut kemudian dianalisis untuk mengetahui pengaruhnya. Analisis data menggunakan teknik statistik, dengan rumus bangun t-score.

\section{Hasil Penelitian}

\section{Deskripsi Data}

a. Deskripsi data skor hasil isian angket tentang kedisiplinan penggunaan waktu untuk belajar siswa pria, dengan rentangan skor antara 1-60 adalah sebagai berikut: $\mathrm{N}=30 ;$ Mean $=40,57$ Median $=37,5 ;$ Mode $=38 ; \mathrm{SD}=6,383 ;$ Skor

maksimal $=50 ;$ dan $\quad$ Skor minimal $=33$. Atas dasar deskripsi data tersebut kemudian disusun tabel 1 berikut. 
Tabel 1. Skor kedisiplinan penggunaan waktu luang untuk belajar siswa pria $(\mathrm{X})$

\begin{tabular}{|c|c|c|}
\hline $\mathbf{I}$ & $\mathbf{X}_{\mathbf{i}}$ & $\mathbf{f}$ \\
\hline $48-50$ & 50 & 4 \\
\hline $45-47$ & 47 & 5 \\
\hline $42-44$ & 44 & 7 \\
\hline $39-41$ & 41 & 8 \\
\hline $36-38$ & 38 & 3 \\
\hline $33-35$ & 35 & 3 \\
\hline Total: & -- & 30 \\
\hline
\end{tabular}

b. Deskripsi data skor hasil isian angket tentang kedisiplinan penggunaan waktu luang untuk belajar siswa wanita, dengan rentangan skor antara 1-60 adalah sebagai berikut: $\mathrm{N}=30 ; \quad$ Mean $=40,57 ; \quad$ Mode $=39 ;$ Median $=$ 37,5; $\mathrm{SD}=5,878$; Skor maksimal $=59$; dan skor minimal $=39 . \quad$ Atas dasar deskripsi data tersebut kemudian disusun tabel 2 berikut:

Tabel 2. Deskripsi Skor Hasil Isian Angket Kedisiplinan Penggunaan Waktu Luang Untuk Belajar Siswa Wanita.

\begin{tabular}{|c|c|c|}
\hline $\mathbf{I}$ & $\mathbf{Y}_{\mathbf{i}}$ & $\mathbf{f}$ \\
\hline $57-59$ & 58 & 1 \\
\hline $54-56$ & 55 & 4 \\
\hline $51-53$ & 52 & 2 \\
\hline $48-50$ & 49 & 2 \\
\hline $45-47$ & 46 & 7 \\
\hline $42-44$ & 43 & 6 \\
\hline $39-41$ & 40 & 8 \\
\hline Total: & -- & 30 \\
\hline
\end{tabular}




\section{Hasil Analisis Data Penelitian}

Tabel 3. Persiapan untuk menghitung t-test pengaruh kedisiplinan penggunaan waktu luang untuk belajar antara siswa pria dengan siswa wanita kelasXI SMA PGRI Maospati tahun pelajaran 2010-2011

\begin{tabular}{|c|c|c|c|c|c|c|c|c|}
\hline Interval & $\mathrm{X}$ & $\mathrm{f}$ & $\mathrm{fX}$ & $\mathbf{f X}^{\mathbf{2}}$ & $\mathrm{Y}$ & $\mathrm{f}$ & $\mathrm{fY}$ & $\mathbf{f Y}^{\mathbf{2}}$ \\
\hline $57-59$ & 58 & 0 & 0 & 0 & 58 & 1 & 58 & 3364 \\
\hline $54-56$ & 55 & 0 & 0 & 0 & 55 & 4 & 220 & 12100 \\
\hline $51-53$ & 52 & 0 & 0 & 0 & 52 & 2 & 104 & 5408 \\
\hline $48-40$ & 49 & 3 & 147 & 7203 & 49 & 2 & 98 & 4802 \\
\hline $45-47$ & 46 & 3 & 138 & 6348 & 46 & 7 & 322 & 14812 \\
\hline $32-44$ & 43 & 5 & 215 & 9245 & 43 & 6 & 258 & 11094 \\
\hline $39-41$ & 40 & 4 & 160 & 6400 & 40 & 3 & 120 & 4800 \\
\hline $36-38$ & 37 & 9 & 333 & 12321 & 37 & 2 & 74 & 2738 \\
\hline $33-35$ & 34 & 6 & 204 & 6936 & 34 & 3 & 102 & 3468 \\
\hline Total & - & 30 & 1197 & 48453 & - & 30 & 1356 & 62586 \\
\hline
\end{tabular}

Berdasarkan data pada tabel 3 di atas, maka langkah selanjutnya memasukkan ke dalam rumus bangun t-tes sebagai berikut.

Diketahui:
$\mathrm{N}=30$
$\mathrm{N}=30$
$\mathrm{Mx}=39,9$
$\mathrm{My}=45,2$
$\mathrm{SD}_{\mathrm{x}}^{2}=23,09$
$\mathrm{SD}_{\mathrm{y}}^{2}=43,16$
$\mathrm{SD}^{2} \mathrm{M}_{\mathrm{X}}=0,796$
$\mathrm{SD}^{2} \mathrm{My}=1,4883$
$\mathrm{SDb}_{\mathrm{M}}=1,5114$
t-tabel $=2,045 / \mathrm{TS}=5 \%$

Harga t-hitung $=3,507$, sedang harga t-tabel dengan $\mathrm{N}=29=2,045$. Jadi $\mathrm{t}-$ hitung lebih besar t-tabel (signifikan), harus dinyatakan bahwa ada perbedaan kedisiplinan penggunaan waktu luang untuk belajar antara siswa pria dengan siswa wanita. Hipotesis yang dikemukakan dalam penelitian ini harus diterima atas dasar taraf signfikansi sebesar 5\%. 
Perbedaan terjadi karena beberapa faktor: (1) siswa wanita lebih disiplin dalam arti lebih taat dalam mengelola waktu luangnya untuk belajar, karena pada umumnya siswa wanita lebih banyak waktu luang berada di dalam rumah. (2) siswa pria, karena sifat kepriaannya lebih aktif dan lebih dinamis dalam beraktivitas, namun sering tidak disertai sikap disiplin dalam mengelola waktu luangnya untuk belajar,

\section{Simpulan dan Saran}

1. Simpulan

a. Ada perbedaan kedisplinan penggunaan watu luang untuk belajar antara siswa pria dan siswa wanita pada siswa kelas XI SMA PGRI 1 Maospati Kabupaten Magetan tahun pelajaran 2010-2011.

b. Kedisiplinan siswa wanita dalam menggunakan waktu luang untuk belajar lebih baik jika dibandingkan dengan siswa pria.

2. Saran

a. Disarankan kepada semua para siswa, khususnya siswa pria, untuk lebih mendisiplinkan dirinya untuk belajar demi perkembangan dan hidup masa depanagar masa depannya.

b. Disarankan kepada fihak sekolah untuk menyusun program-program yang banyak melibatkan para siswa, sehingga banyak waktu dapat dimanfaatkan pada aktivitas positif, termasuk dalam menggunakan waktu luangnya untuk belajar.

\section{Daftar Pustaka}

Depdiknas. 2005. Kamus Besar Bahasa Indonesia. Jakarta: Balai Pustaka.

Dekdiknas (2007). Tata Tertib Sekolah Menengah Atas Dan Kejuruan. Propinsi Jawa Timur.Slameto. 2005. Belajar Dan Faktor-Faktor Yang Mempengaruhinya. Jakarta: Bina Aksara. 
Dewa Ketut Sukardi. 2002. Pengantar Pelaksanaan Program Bimbingan dan Konseling di Sekolah. Jakarta: Rineka Cipta.

M. Ngalim Purwanto. 2006. Psikologi Pendidikan. Bandung: PT Remaja Rosdakarya Offset.

Mary Perkins, Ryan, and John Julian Ryan. 1994. Hidup, Cinta dan Seks. Yogyakarta: Penerbit Kanisius.

Moh. Shochib. 2000. Pola Asuh Orang Tua Dalam Membantu Anak Mengembangkan Disiplin Diri. Jakarta: Rineka Cipta.

Shah Muhibin. 1995. Psikologi Pendidikan, Suatu Pendekatan Baru. Bandung: Remaja Rosdakarya.

Saifuddin Azwar dan Sanapiah Faisal. 1990. Format-Format Penelitian Sosial. Jakarta: Rajawali Pers.

Sarwoyo. 2006. Skripsi Program Studi Bimbingan dan Konseling, Fakultas Ilmu Pendidikan IKIP PGRI Madiun.

Sumadi Suryabrata. 2004. Psikologi Pendidikan. Jakarta: PT. Raja Grafindo Persada.

Sutrisno Hadi,. 1992. Statistik 2. Yogyakarta. Penerbit Andi Offset.

Vitalis, DS. 2002. Perilaku Manusia. Diktat Mata Kuliah Prodi BK Fakultas Ilmu Pendidikan IKIP PGRI Madiun.

Vitalis, DS. 2003. Panduan Layanan Bimbingan dan Konsleing di Sekolah Menengah. Diktat Mata Kuliah Prodi BK Fakultas Ilmu Pendidikan IKIP PGRI Madiun.

Wayan Nurkancana dan Sumartana. 1996. Evaluasi Pendidikan. Surabaya: Usaha Nasional.

Winarno Surakhmad, 1992. Metodologi Penelitian Ilmiah. Sebuah Pengantar, Dasar, Metoda, dan Teknik. Bandung: Tarsito.

WS`Winkel.. 1992. Psikologi Pendidikan di Institusi Pendidikan. Jakarta Penerbit PT Gramedia.

WS Winkel.. 1994. Psikologi Pendidikan dan Evaluasi Belajar. Jakarta Penerbit PT Gramedia.

W.J.S. Poerwadarminta. 1986. Kamus Bahasa Indonesia. Jakarta: PN. Balai Pustaka 
